Bp Józef Wróbel SCJ

Katolicki Uniwersytet Lubelski

\title{
Bioetyka a wiara
}

\section{BIOETHICS AND FAITH}

The problem of a relation between bioethics and faith is complex when it refers to Christian religion. It begins on the plane of the relationship between philosophy and Christian philosophy, more exactly, of the disputable question whether philosophy can have a Christian character. In the light of methodological principles, philosophy (the natural one) seems to exclude religious motives in advance. A similar problem can be observed in the field of ethics. In its proper sense, it is a philosophical science (as has been stated in the above definitions of bioethics). If so, ethics is, in its wrong sense, a form of moral theology, as it has occurred in the so-called 'theological ethics' being the field of research of some authors.

Key words: bioethics, faith, Christian ethics, natural bioethics, Christian bioethics, biomedicine, personalistic norm

Bioetyka doczekała się już uznanych definicji. Jedna z pierwszych jest autorstwa W. T. Reicha, twórcy Encyklopedii bioetyki. Fakt ten zasługuje na osobne podkreślenie, gdyż tak trzytomowe dzieło, jak i pojawiająca się w nim definicja, zostały opublikowane zanim ostatecznie sprecyzowano przedmiot i zakres wiedzy, które opisują ${ }^{1}$. W powyższym ujęciu bioetyka to ,studium systematyczne ludzkiego postępowania 
w sferze nauk związanych z ludzkim życiem i ochroną zdrowia, dokonywane w świetle wartości i zasad moralnych"2.

Definicję tę należy zaliczyć do otwartych. Dosyć ogólnie mówi ona o kącie formalnym bioetyki. Wprawdzie podkreśla, że właściwa dla niej refleksja jest czyniona w świetle wartości i zasad moralnych, ale nie precyzuje, jakie wartości i jakie zasady ma na myśli. Jej twórca, w sposób klasyczny dla środowisk anglosaskich, zdaje się w ten sposób pozostawiać wolną przestrzeń dla różnych systemów aksjologicznych i zasad, w tym również przesłanek pragmatycznych, filozoficznych, prawnych i religijnych. Każdy może dokonywać moralnych ocen z własnego punktu widzenia. Każdy system aksjologiczny może też stanowić podstawę dla skonkretyzowanych ocen etycznych. Mając na uwadze przedmiot niniejszych analiz, jest tutaj również miejsce na perspektywę chrześcijańską i związane z nią prawdy wiary.

Bardziej precyzyjna jest definicja autorstwa ks. prof. Tadeusza Biesagi SDB. Według niego bioetyka to „wyspecjalizowana część filozoficznej etyki szczegółowej, ustalająca oceny i normy moralne w stosunku do ingerencji w życie ludzkie w granicznych sytuacjach jego powstawania (biogeneza), trwania (bioterapia) i śmierci (tanatologia)”3. Analogiczną definicję podaje O. Tadeusz Ślipko SJ: „Bioetyka stanowi dział filozoficznej etyki szczegółowej, która ma ustalić oceny i normy (reguły) moralne ważne w dziedzinie działań (aktów) ludzkich, polegających na ingerencji w granicznych sytuacjach związanych z zapoczątkowaniem życia, jego trwaniem i śmiercią"4.

Określenia bioetyki T. Biesagi i T. Ślipko mają ewidentnie na uwadze założenia metodologiczne, bez których nie można uprawiać żadnej nauki. Wskazują one na charakter filozoficzny bioetyki. Wprawdzie nie precyzują, jaki system filozoficzny mają na uwadze, ale przez postawienie takiego akcentu ewidentnie zakładają odwołanie do naturalnych źródeł poznania i racjonalnej refleksji. Czy jednak takie stanowisko przekreśla możliwość uprawiania bioetyki chrześcijańskiej, w tym sięgającej do przesłanek teologicznych? To niełatwy, ale i interesujący problem, domagający się pogłębionej refleksji.

2 Introduction, [w:] Encyclopedia of Bioethics, W. T. Reich (red.), t. 1, New York 1978, s. XIX.

3 T. Biesaga, Bioetyka, [w:] Encyklopedia bioetyki. Personalizm chrześcijański. Głos Kościoła, Radom 2005, s. 54-55. 


\section{Czy bioetyka potrzebuje wiary?}

Problem relacji między bioetyką i wiarą w przypadku religii chrześcijańskiej jest bardzo złożony. Zaczyna się on już na płaszczyźnie relacji między filozofią i filozofią chrześcijańską, a właściwie sporu, czy filozofia może mieć charakter chrześcijański. W świetle zasad metodologicznych filozofia (naturalna) zdaje się z góry wykluczać motywy religijne. Analogicznie rzecz się ma z etyką. Nauka ta w sensie właściwym jest nauką filozoficzną (na co wskazały już powyższe dwie definicje bioetyki). Jeżeli już, to w sensie niewłaściwym etyka jest formą teologii moralnej, jak to miało miejsce w przypadku ,etyki teologicznej" uprawianej przez niektórych autorów ${ }^{5}$.

\section{Między filozofią i filozofią chrześcijańską}

Powyższe uwagi sugerują, iż z punktu widzenia metodologicznego filozofia i etyka nie odnoszą się do wiary. Są one autonomicznymi naukami posługującymi się własnymi metodami i jako takie są w stanie dojść do spójnych, racjonalnie uprawnionych konkluzji. Czy to jednak oznacza, że wiara nie jest w stanie wnieść żadnych treści do filozofii i etyki albo nawet, że filozofia i etyka wprost ją wykluczają? Poszukiwania naukowe czynione $\mathrm{w}$ połowie XX wieku (w Polsce w latach siedemdziesiątych tegoż wieku), a cząstkowo podjęte na nowo po opublikowaniu encykliki Jana Pawła II Fides et ratio, sugerują, że odpowiedź na to pytanie jest uzależnione od odpowiedzi na pytanie o naturę filozofii, a w dalszej perspektywie również etyki. Ponownie wynurza się tutaj problem, czy tym naukom absolutnie obce są przesłanki wychodzących poza przyrodzone zdolności poznawcze człowieka?

Raczej jest rzeczą niemożliwą, aby filozofia i etyka były uprawiane w sterylnych warunkach na wzór matematyki, fizyki czy chemii. Pewne przesłanki płyną już z rozumienia filozofii i etyki. Pierwsza z nich jest określana jako „historycznie zmienna (co do problematyki i metody) dziedzina ogólnych dociekań nad najgłębszą racją, strukturą lub sensem rzeczywistości oraz ostatecznymi warunkami wartościowego poznania lub naczelną zasadą postępowania człowieka" ${ }^{6}$. Ta druga jest powszechnie uznawana za „naukę normatywną, która, opierając

$5 \quad$ Por. np. Handbuch der christlichen Ethik, 3 t., Freiburg-Basel-Wien 1978-1982; M. Vidal, Manuale di etica teologica, 4 t., Assisi 1994-1997; K-H. Peschke, Christiche Ethik. Grundlagen der Moraltheologie, 2 t., Trier 1995-1997.

6 S. Kamiński, Filozofia, [w:] Encyklopedia Katolicka, t. 5, L. Bieńkowski (red.), Lublin 1989, kol. 242. 
się na danych doświadczenia i zasadach rozumowych, zmierza do sformułowania ocen i norm moralnych"7.

W definicji etyki na szczególną uwagę zasługuje podkreślenie roli „doświadczenia” i ,zasad rozumowych” jako odpowiednika poznania w definicji filozofii. Można przez nie rozumieć racjonalną interpretację uniwersalnego przeżycia, będącego udziałem ludzkiego sumienia jako bezpośredniej normy moralności. Ujawniające się w nim doświadczenie radości afirmuje spełniony czyn jako moralnie dobry, a doświadczenie przykrości i wyrzutów daje świadectwo o moralnym złu danego czynu. O uniwersalności i charakterze imperatywnym tego doświadczenia piszą myśliciele wszystkich czasów. O nim mówi też św. Paweł Apostoł w Liście do Rzymian: „Nie ci bowiem, którzy przysłuchują się czytaniu Prawa [chodzi tutaj o Prawo Mojżeszowe], są sprawiedliwi wobec Boga, ale ci, którzy Prawo wypełniają, będą usprawiedliwieni. Bo gdy poganie, którzy Prawa nie mają, idąc za naturą, czynią to, co Prawo nakazuje [...]. Wykazują oni, że treść Prawa wypisana jest $\mathrm{w}$ ich sercach, gdy jednocześnie ich sumienie staje jako świadek, a mianowicie ich myśli na przemian ich oskarżające lub uniewinniające" $(2,13-15)$.

Przez to doświadczenie można również rozumieć powszechne i trwałe przekonanie ludzi, co do obowiązku przestrzegania zasad moralnych i czynienia dobra, a konsekwentnie także, co do wartości moralnej konkretnych czynów. Czyny dobre znajdują coraz powszechniejszą afirmację, a w wielu przypadkach doczekały się uznania w postaci zasad i kodyfikacji, jak na przykład tzw. „złota reguła” znana od najdawniejszych czasów (głosił ją między innymi Konfucjusz, Budda Siakjamuni, Tales z Miletu, Pittakos z Mityleny $)^{8}$. Czyny nieetyczne, chociaż niekiedy głęboko wpisane w przekonania i kulturę jednostek czy też grup ludzi, z upływem czasu ulegają weryfikacji i zostają zaniechane, odrzucone, a inne potępione, niekiedy dopiero przez historię, gdyż uznane za niegodne człowieka. Pragnienie i wyczucie dobra

T. Ślipko, Bioetyka. Najważniejsze problemy, Kraków 2009, s. 14.

Stary Testament i liczne pisma żydowskie pozabiblijne podawały „,złotą regułę” w formie negatywnej: „Czym sam się brzydzisz, nie czyń tego nikomu!” (Tb 4, 15; Mdr 31, 15). Pan Jezus formułuje ją pozytywnie „Wszystko więc, co byście chcieli, żeby wam ludzie czynili, i wy im czyńcie. Albowiem na tym polega Prawo i Prorocy” (Mt 7, 12; Łk 6, 13). W powszechnym sformułowaniu brzmi ona „Nie czyń drugiemu, co tobie niemiłe" (por. A. Sand, G. W. Hunold, Goldene Regel, [w:] Lexikon der christlichen Ethik, G. W. Hunold (red.), t. 1, Freiburg - Basel - Wien 2003, s. 745-748; J. Fuchs, Die schwierige Goldene Regel, „Stimmen der Zeit" (1991) nr 11, s. 773-781; Ch. Theobald, La régle d'or chez Paul Ricoeur. Une interrogation théologique, „Recherches de Science Religieuse” 83(1995), nr 1, s. 43-59. 
nurtuje najpierw ludzkie serca, a następnie inicjuje transformację obyczajów, systemów, czy też struktur społecznych i politycznych. Badania z zakresu etnologii, religiologii, a dziś najczęściej socjologii, wykazują, że doświadczenia te bardzo często są kształtowane przez wiarę i przekonania religijne. Takie właśnie oddziaływanie Ewangelii daje się zauważyć w procesie cywilizowania ludów czy to starożytnych (np. przezwyciężenie kultu religijnego w postaci ofiar składanych z ludzi, zwalczanie niewolnictwa, znoszenie poligamii), czy też współczesnych (np. zaniechanie kary śmierci, promocja godności i praw człowieka, świętości życia ludzkiego od poczęcia do naturalnej śmierci). Takie doświadczenia stanęły też u podstaw rozwoju systemów filozoficznych i zbudowanych na nich koncepcji etycznych.

Mając na uwadze powyższy kontekst cytowany, o. Tadeusz Ślipko SJ mówi nie tylko o uprawianiu etyki, ale wprost etyki chrześcijańskiej. Podkreśla on, że nie chodzi tutaj o mieszanie metodologiczne dwóch nauk. „Używając tego określenia [etyki chrześcijańskiej], ma na myśli fakt, że interesujący go system filozoficzno-etyczny zrodził się w bardzo «chrześcijańskiej» epoce średniowiecza, że jego fundamenty i centralne wiązania są dziełem myśli dla chrześcijaństwa reprezentatywnych filozofów (...), a wreszcie, że jest pielęgnowany i wciąż rozbudowywany w ramach kościelnych instytucji naukowo-dydaktycznych"9.

$\mathrm{Na}$ powyższy problem filozofii chrześcijańskiej i konsekwentnie etyki chrześcijańskiej można spojrzeć jeszcze z innej perspektywy. Chodzi tutaj o analizowaną m.in. przez Jacquesa Maritaina i Etienne Gilsona możliwość uprawiana filozofii chrześcijańskiej. Metodologicznie poprawne jest stwierdzenie, wyrażone już wcześniej, iż filozofia jako nauka oparta na przesłankach rozumowych i racjonalnej analizie nie powinna się odwoływać do przekonań religijnych i do wiary. Takie odwołanie jest metodologicznie błędne, gdyż miesza porządek naturalny z porządkiem nadprzyrodzonym. Etienne Gilson wykazywał jednak, że filozofia nie może osiągnąć swej pełni bez metafizyki, a z kolei metafizyka bez Boga. Stąd dla chrześcijanina Objawienie

9 T. Ślipko, Bioetyka. Najważniejsze problemy, Kraków 2009, s. 14; także tenże, Granice życia. Dylematy wspótczesnej bioetyki, Kraków 1994, s. 14-15; także: tenże, Zarys etyki ogólnej, Kraków 2009, s. 19. Więcej na temat filozofii chrześcijańskiej [w:] Jan Paweł II, Encyklika Fides et ratio, Rzym 1998, 76: „Mówiąc o filozofii chrześcijańskiej mamy na myśli wszystkie ważne kierunki myśli filozoficznej, które nie powstałyby bez bezpośredniego lub pośredniego wkładu wiary chrześcijańskiej”. Por. także W. Chudy, Filozofia chrześcijańska - rozum i wiara, [w:] Jan Pawet II. Fides et ratio. Tekst i komentarze, T. Styczeń (red.), Lublin 2003, s. 283-303. 
jest dopełnieniem refleksji filozoficznej ${ }^{10}$. Jacques Maritain był z kolei przekonany, że sama filozofia, jak długo pozostaje na poziomie naturalnych zdolności poznawczych, nie jest w stanie wyjść poza to, co sam człowiek jest zdolny poznać i zrozumieć. Jednakże myślący i głodny prawdy człowiek od zawsze szuka ostatecznych racji i stawia sobie pytania, które przekraczają jego możliwości poznawcze. Dotyczy to m.in. pytań o pierwszą przyczynę wszystkich rzeczy, o pochodzenie człowieka, o sens jego życia i wolności, o sens cierpienia, o kres życia, ale także o istotę i sens dobra ${ }^{11}$. Czy konsekwentnie filozofia, która nie jest w stanie dać odpowiedzi na te pytania, napotyka trudną do pokonania barierę, może być uznana za prawdziwą mądrość wyznaczającą orientację życiową i konkretne wybory człowieka?

Pojawiają się dwie możliwości rozwiązana tego dylematu: albo człowiek wychodzi poza ramy uprawiania filozofii i oddaje się teologii, albo też swoją myśl filozoficzną uzupełnia o przesłanki czy inspiracje płynące z Objawienia (stroniąc przy tym od postaw irracjonalnych i fideistycznych). Taką szansę J. Maritain upatruje w filozofii chrześcijańskiej i stąd jej szczególna wartość. Swoje znaczenie zawdzięcza ona temu, że kształtowała się w klimacie chrześcijaństwa i konsekwentnie jest wewnętrznie zgodna $\mathrm{z}$ wiarą chrześcijańską ${ }^{12}$. Taką możliwość widzi przytaczany wyżej o. T. Ślipko. Dochodzi on do wniosku, że filozofia czy etyka filozoficzna nie odrzuca w swych odgórnych założeniach „teologicznych źródeł poznania”. „Jeżeli znajduje w nich elementy treściowe filozoficznie znaczące, bierze je chętnie na swój użytek" ${ }^{13}$. Słuszność powyższych spostrzeżeń afirmuje w końcu Jan Paweł II w encyklice Fides et ratio. Stwierdza on, że „bez pobudzającego wpływu Słowa Bożego nie powstałaby znaczna część filozofii nowożytnej i współczesnej. Fakt ten zachowuje całe swoje znaczenie nawet w obliczu smutnej konstatacji, że wielu myślicieli ostatnich stuleci odeszło od chrześcijańskiej ortodoksji" ${ }^{14}$.

Powyższe stwierdzenia mogą rodzić podejrzenie o nienaukowość i skrajną subiektywizację refleksji filozoficznej. Może się wydawać, że

10 Por. Chrystianizm a filozofia, Warszawa 1988.

11 Por. Jan Paweł II, Encyklika Fides et ratio, Rzym 1998, 16-19; por. także A. Maryniarczyk, M. A. Krąpiec, Filozofia [M. A. Krąpiec, Klasyczne rozumienie filozofii], [w:] Powszechna encyklopedia filozofii, A. Maryniarczyk (red.), t. 3, Lublin 2002, s. 453-478.

Por. J. Maritain, O filozofii chrześcijańskiej, [w:] Pisma filozoficzne, Kraków 1988, s. 132-141. 
prawda nie ma charakteru obiektywnego, ale jej źródłem sąjakieś inne kryteria i punkty odniesienia, to znaczy wiara, tradycja, autorytet czy intuicja. Szeroka dyskusja na temat naukowości egzegezy biblijnej, refleksji teologicznej, racjonalności i obiektywizmu chrześcijańskiej mistyki, a zwłaszcza przemyślenia zawarte w encyklice Jana Pawła II Fides et ratio, pozwalają zrozumieć, że kryteria te nie muszą się jednak wymykać spod kontroli rozumu i możliwości weryfikacji prawdziwości właściwego im poznania. Wprost przeciwnie, Objawienie Boże, wiara, poznanie mistyczne muszą w swej treści podlegać procesowi uwiarygodnienia na drodze weryfikacji rozumowej ${ }^{15}$. Irracjonalny charakter ma raczej wykluczenie a priori istnienia Boga i odrzucenie Go jako źródła Mądrości, Prawdy i Dobra.

Powyższą część rozważań można podsumować konkluzją, iż tak filozofia, jak i etyka filozoficzna są samowystarczalne na poziomie naturalnej refleksji. Jeżeli one jednak szukają pełnej odpowiedzi na nurtujące człowieka pytania o prawdę i dobro, to musi on mieć odwagę odkrywania i poznawania głębszych źródeł mądrości, które wykraczają poza jego przyrodzone zdolności poznawcze. Te źródła nie wykluczają jego rozumności, ale ją zakładają, na niej bazują i w niej są rozpoznawane jako prawdziwe. Jan Paweł II napisał w tym względzie: „Istnieje [...] aspekt obiektywny, dotyczący treści filozofii: Objawienie ukazuje wyraźnie pewne prawdy, których rozum być może nigdy by nie odkrył, gdyby był zdany na własne siły, choć nie są one niedostępne dla jego naturalnego poznania. Należą do tej dziedziny takie zagadnienia, jak pojęcie Boga Stwórcy osobowego i wolnego, które odegrało tak znaczącą rolę w rozwoju myśli filozoficznej, a zwłaszcza filozofii bytu. W tej sferze mieści się także rzeczywistość grzechu, tak jak jawi się ona w świetle wiary, która pomaga poprawnie ująć w kategoriach filozoficznych problem zła. Także koncepcja osoby jako istoty duchowej

15 Por. Jan Paweł II, Encyklika Fides et ratio, Rzym 1998, 48: „Wiara, pozbawiona oparcia w rozumie, skupiła się bardziej na uczuciach i przeżyciach, co stwarza zagrożenie, że przestanie być propozycją uniwersalną. Złudne jest mniemanie, że wiara może silniej oddziaływać na słaby rozum; przeciwnie, jest wówczas narażona na poważne niebezpieczeństwo, może bowiem zostać sprowadzona do poziomu mitu lub przesądu. Analogicznie, gdy rozum nie ma do czynienia z dojrzałą wiarą, brakuje mu bodźca, który kazałby skupić uwagę na specyfice i głębi bytu”. W innym miejscu Papież pisze: „Obiektywnym elementem filozofii chrześcijańskiej jest też konieczność badania racjonalności pewnym prawd zawartych w Piśmie Świętym, takich jak możliwość nadprzyrodzonego powołania człowieka czy sam grzech pierworodny" (tamże, 76); por. także nry 13-15; 36-48; Kongregacja Nauki Wiary, Instrukcja o powotaniu teologa w Kościele, Watykan 1990, 9; M. Rusecki, Wiarygodność, [w:] Leksykon teologii fundamentalnej, M. Rusecki (red.), Lublin - Kraków 2002, s. 1328-1334. 
jest szczególnie oryginalnym wkładem wiary: chrześcijańskie orędzie godności, równości i wolności ludzi bez wątpienia wywarło wpływ na nowożytną refleksję filozoficzną"16.

\section{Między bioetyką naturalną i bioetyką chrześcijańską}

Bioetyka pozostaje w bezpośrednim związku z biomedycyną troszczącą się o zdrowie i życie człowieka. Ten związek nie zawsze jest oczywisty i domaga się pogłębionej refleksji.

\subsection{Między bioetyką i biomedycyną}

W pewnych ramach biomedycyna jest widziana jako nauka autonomiczna, będąca syntezą określonej wiedzy teoretycznej z zakresu nauk pokrewnych, kierująca się własną metodą poznawczą oraz badawczą. W tym kontekście wszelkie refleksje meta-medyczne jawią się jako zbędne dywagacje umiejscowione poza ramami merytorycznymi i nie wnoszące istotnych treści do jej rozwoju. Zwolennicy takiego stanowiska powołują się też na stwierdzenie papieża Pawła VI, iż Kościół i teologia nie są instancjami kompetentnymi w kwestiach medycyny ${ }^{17}$.

Powyższa wypowiedź Papieża odnosi się jednak do płaszczyzny metodologicznej biomedycyny. W swej istocie nie jest ona wyłącznie nauką teoretyczną interesującą się wewnętrzną strukturą i prawami regulującymi procesy biologiczno-fizjologiczne zachodzące w ludzkim organizmie, a zwłaszcza przyczyną i naturą stanów patologicznych oraz możliwością ich naprawienia. Równie bardzo jest ona praktyką bazującą na nabytej wiedzy i na doświadczeniu. Bioetyk powie, że każdy akt praktyki biomedycznej jest specyficznym czynem ludzkim, i jako taki jest przedmiotem moralnej oceny w świetle określonego systemu wartości, a ostatecznie w świetle zrozumienia samego człowieka. Od tegoż zrozumienia zależy bowiem określenie tego, co dla niego jest dobre i co mu jest należne.

Powyższy związek między bioetyką i biomedycyną staje się jeszcze bardziej zrozumiały, jeżeli się uwzględni fakt, że bioetyka i biomedycyna, mają wspólny przedmiot zainteresowania, a jest nim człowiek. Stąd też bioetyka w tej mierze interesuje się biomedycyną i na tyle to zainteresowanie jest metodologicznie uprawnione, na ile człowiek

16 Jan Paweł II, Encyklika Fides et ratio, Rzym 1998, 76.

17 Por. Paweł VI, I partecipanti ai congressi internazionali di chirurgia generale e di chirurgia cardio-vascolare. Przemówienie do członków Międzynarodowego Towarzystwa Chirurgicznego i Towarzystwa Chirurgii Sercowo-Naczyniowej (20.09.1963), [w:] PVIIns, t. 1. 1963, Vaticano, s. 139-140. 
z jednej strony jest podmiotem, a z drugiej strony osobowym przedmiotem biomedycyny; a ściślej, na ile biomedycyna jest narzędziem dobra w rękach specjalisty - podmiotu biomedycyny - i na ile służy ona dobru drugiego człowieka - osobowemu przedmiotowi praktyki biomedycznej ${ }^{18}$.

Tak rozumiana relacja między bioetyką i biomedycyną nie ma wyłącznie charakteru jednostronnego. Bioetyka wypełniająca adekwatnie swoje posłannictwo nie wyraża się wyłącznie w ocenie działań biomedycznych post factum. Jej wkład wyraża się również w oddziaływaniu ante factum, to znaczy w pełnieniu roli kryterium w doborze środków i metod służących osiągnięciu zamierzonego celu. I tutaj pojawia się jako nieodzowny punkt wyjścia problem koncepcji człowieka, której nie można zbudować bez odwołania do przesłanek filozoficznych, a mając na uwadze refleksje przedstawione w pierwszej części, również do przesłanek teologicznych, dla których wiara jest źródłem poznania i prawdy o człowieku.

Jak już podkreślono, takie postawienie problemu bioetyki w świetle niektórych jej ujęć wydaje się być zbędne. Można się spotkać ze stwierdzeniem, iż pełniący praktykę biomedyczną kieruje się potrzebą pacjenta (dziś coraz częściej klienta), a spełniając jego oczekiwania, bazuje przede wszystkim na posiadanej wiedzy i doświadczeniu. Podstawowym kryterium etycznym jest więc postępowanie zgodne z zasadami sztuki biomedycznej (lege artis).

Opinia taka jest jednak sporym uproszczeniem. Jej słuszność podważa już sam fakt, że od starożytności praktyka lekarska i medyczna uznała za konieczne formułowanie i kodyfikowanie etycznych wymogów postępowania. Wystarczy przypomnieć Kodeks Hipokratesa czy Majmonidesa, a także współczesne kodeksy, deklaracje, rekomendacje i konwencje, jak na przykład Deklaracja Genewska, Helsinska, Lizbońska, z Oslo, z Sydney czy $z$ Tokio, czy też dokument Rady Europy z Oviedo O ochronie praw człowieka i godności istoty ludzkiej w kontekście zastosowań biologii i medycyny. Konwencja o prawach człowieka i biomedycynie (z 4.04.1997 roku), czy też polski Kodeks Etyki Lekarskiej z 2.01.2004 roku uzupełniony Ustawa 1149 z dnia 1.07.2005 roku o pobieraniu, przechowywaniu i przeszczepianiu komórek, tkanek i narząów ${ }^{19}$.

18 Por. np. Paweł VI, VII Congresso della Unione Medica Latina. Przemówienie do uczestników VII Międzynarodowego Kongresu Lekarzy przynależących do Unione Medica Latina (21.03.1964), [w:] PVIIns, t. 2, 1964, Vaticano 1965, s. 196, 197.

19 Por. J. Wróbel, Lekarska etyka, [w:] Encyklopedia Katolicka, t. 10, E. Ziemann (red.), Lublin 2004, kol. 704-706, 711-712; tenże, Lekarz, [w:] Encyklopedia katolicka, t. 10, E. Ziemann (red.), Lublin 2004, kol. 711-712; tenże, Medyczna etyka, 
Powyższe ujęcia zobowiązań przedstawicieli biomedycyny bazują na fundamentalnej normie deontologicznej. Aktualnie obowiązujący w Polsce Kodeks Etyki Lekarskiej ujmuje ją w słowach: „Powołaniem lekarza jest ochrona życia i zdrowia ludzkiego, zapobieganie chorobom, leczenie chorych oraz niesienie ulgi w cierpieniu; lekarz nie może posługiwać się wiedzą i umiejętnością lekarską w działaniach sprzecznych z jego powołaniem" (Art. 2, p. 1). Jednocześnie dodaje: „Najwyższym nakazem etycznym lekarza jest dobro chorego - salus aegroti suprema lex esto” (Art. 2, p. 2) oraz „Lekarz powinien zawsze wypełniać swoje obowiązki z poszanowaniem człowieka" (Art. 3).

Powyższe ujęcia wskazują na istotną różnicę między etyką postępowania zgodnie z zasadą lege artis i etyką przytoczonych sformułowań kodeksowych. W pierwszym przypadku akcent jest położony na sztukę medyczną. W drugim przypadku na człowieka. Twórcy Kodeksu uważają więc, że najważniejszą rzeczą dla praktyki medycznej, jest nie tylko działanie zgodnie $\mathrm{z}$ wiedzą i doświadczeniem, ale również dobro człowieka. Te dwa wymiary mogą, ale nie muszą się ze sobą pokrywać. $\mathrm{Z}$ reguły pokrywają się $\mathrm{w}$ prostych zabiegach ratujących zdrowie czy życie pacjenta. W przypadkach przekraczających ramy prostej terapii te wymiary mogą się jednak rozchodzić, i to niekiedy radykalnie. Innymi słowy, biomedycyna uprawiana zgodnie z zasadami sztuki, nie zawsze czyni zadość postulatom wysuwanym przez integralnie rozumiane dobro człowieka. Jako przykład może posłużyć szeroko dyskutowana dziś procedura in vitro. Zdaje się ona służyć niepłodnym małżonkom, bo pozwala im mieć upragnione dziecko. Ale to tylko jeden wymiar tej techniki. W rzeczywistości prokreacja technicyzowana nie liczy się z godnością małżonków i ich dziecka, niesie ze sobą śmierć wielu embrionów i jest źródłem licznych negatywnych skutków dla ich zdrowia ${ }^{20}$. Te efekty trudno uznać za zgodne z ideałami stojącymi u podstaw lekarskiego etosu i inspirującymi samą praktykę. Trudno je nawet uznać za niechciany skutek uboczny, skoro w tej procedurze więcej embrionów ginie, niż się rodzi. Podobne dylematy powstają

[w:] Encyklopedia katolicka, t. 12, E. Ziemann (red.), Lublin 2008, kol. 425-427; A. Labisch, N. Paul, Ärztliche Gelöbnisse, [w:] Lexikon der Bioethik, W. Korff (red.), t. 1, Gütersloh 1998, s. 249-255; J. Zabielski, Kodeks deontologiczny pracowników stużby zdrowia, „Collectanea Theologica” 66 (1996) nr 4, s. 129-134; Lekarza prawa człowieka. Normyi wskazania orzecznictwa międzynarodowego, etyki oraz moralności katolickiej, protestanckiej, żydowskiej, muzutmańskiej, buddyjskiej i agnostycznej, Toruń 1996; Die ärztlichen Gelöbnisse, „Arzt und Christ" 8(1962) nr 1, s. 1-34.

20 Por. J. Wróbel, Prokreacja technicyzowana - wyzwania etyczne, „Roczniki Teologii Moralnej” (2009) nr 1, s. 183-202. 
w przypadku prób preselekcji przymiotów dziecka „tworzonego” metodami sztucznymi, poczynając od jego płci, zwiększania jego wydolności fizycznych czy zdolności intelektualnych. Analogiczne sytuacje powstają w przypadkach niektórych typów chirurgii plastycznej, eksperymentowania wokół stanów terminalnych, całej gamy eksperymentów biomedycznych.

Inny przykład jest związany z historią człowieka, któremu implantowano rękę pobraną z ludzkich zwłok. Swoją własną utracił w nieszczęśliwym wypadku. Operację przeprowadzono z największym profesjonalizmem, zgodnie z zasadami sztuki lekarskiej. Z punktu widzenia medycznego zabieg udał się i pacjent odzyskał władzę w ręce. Wynik końcowy nie był jednak sukcesem. Biorca nie był w stanie zaakceptować przyszytej mu ręki na poziomie psychicznym. Przypominała mu ona zmarłego dawcę. $\mathrm{W}$ trosce o zdrowie psychiczne biorcy trzeba było mu amputować odzyskaną rękę.

Powstaje więc pytanie, w oparciu o jakie kryteria można orzekać dobro, a tym samym etyczność konkretnych projektów czy praktyk biomedycznych? Jeżeli chcieć dać odpowiedź na postawione pytanie, uwzględniając współczesne publikacje bioetyczne, to odpowiedź nie jest prosta. W oczy rzuca się bowiem pluralizm bioetyczny czy też wielość modeli bioetycznych. Wystarczy wspomnieć o pryncypializmie T. L. Beauchampa i J. F. Childressa, bezstronnej teorii reguł K. Dannera Clousera, kazuistyce Alberta Jonsena ${ }^{21}$, etyce cnót Edmunda D. Pellegrino ${ }^{22}$, utylitaryzmie Petera Singera i Johna Harrisa ${ }^{23}$, czy kontraktualizmie-procedualizmie H. T. Engelhardta ${ }^{24}$. Przyznanie racji powyższym propozycjom oznaczałoby nie tylko negację możliwości zbudowania bioetyki o charakterze uniwersalnym, ale wprost istnienie normy uniwersalnej dobra. Jeżeli już takowa istnieje, to trzeba by za

21 Por. G. Hołub, Kazuistyka $w$ poszukiwaniu podstaw moralności, [w:] Systemy bioetyki, T. Biesaga (red.), Kraków 2003, s. 93-115.

Por. T. Biesaga, Personalizm a pryncypializm $w$ bioetyce, [w:] Podstawy $i$ zastosowania bioetyki, T. Biesaga (red.), Kraków 2001, s. 43-44; G. Hołub, Diego Garcia a pryncypializm w bioetyce, [w:] Systemy bioetyki, dz. cyt., s. 23-24.

Por. B. Wójcik, Bioetyka praktyczna Petera Singera, [w:] Systemy bioetyki, dz. cyt., s. 71-92.

Por. H. T. Engelhardt, Manuale di bioetica, Milano 1991; P. Comanducci, Il neocontrattualismo,[w:] Teorie etiche contemporanee, C.A. Viano(red.), Torino 1990 s. 108-128; S. Privitera, Contrattualismo e neocontrattualismo, [w:] Dizionario di Bioetica, red. S. Leone, S. Privitera, Palermo 1994, s. 187-188; G. Hołub, Personalizm i inne propozycje bioetyki, [w:] Bioetyka personalistyczna, T. Biesaga (red.), Kraków 2006, s. 16-17. 
nią uznać „zasadę wolności” i demokratycznego orzekania o tym, co dobre $^{25}$.

Takie stanowisko jest jednak obce tej bioetyce, która podstawy uniwersalizmu znajduje w Powszechnej Deklaracji Praw Człowieka uchwalonej 10.12.1948 roku, a w jakiejś mierze również w Kodeksie Etyki Lekarskiej. Pierwszy z tych dokumentów odwołuje się w preambule, a następnie w pierwszym punkcie do godności człowieka ${ }^{26}$. Z kolei drugi dokument, już na samym wstępie, w artykule pierwszym, podkreśla, że „zasady etyki lekarskiej wynikają z ogólnych norm etycznych” (p. 1) oraz, że „,[normy te] zobowiązują lekarza do przestrzegania praw człowieka i dbania o godność zawodu lekarskiego" (p. 2). Konsekwentnie podstawa orzekania dobra w bioetyce nie może być traktowana dowolnie czy też „demokratycznie”, ale winna być odniesiona do tegoż fundamentu refleksji aksjologicznej, jaki stanowi godność osobowa człowieka i zbudowana na niej tak zwana „norma personalistyczna”. W sformułowaniu Karola Wojtyły brzmi ona: „Norma [personalistyczna] jako zasada o treści negatywnej stwierdza, że osoba jest takim dobrem, z którym nie godzi się używanie, które nie może być traktowane jako przedmiot użycia i w tej formie jako środek do celu. W parze z tym idzie treść pozytywna normy personalistycznej: osoba jest takim dobrem, że właściwe i pełnowartościowe odniesienie do niej stanowi tylko miłość" 27 . Norma ta w dalszej analizie prowadzi do określonych konkluzji normatywnych.

1) Godność człowieka ma charakter powszechny i niezbywalny. Jest więc bez wyjątku udziałem każdego człowieka, bez względu na jego przymioty, gdyż jego geneza i ontologicznie rozumiana natura jest bezwzględnie taka sama. Żadna instytucja, ani żaden człowiek nie udziela jej drugiemu człowiekowi, ani nie może jej go pozbawić.

$25 \quad$ Por. J. Wróbel, Antropologia we wspótczesnej refleksji bioetycznej, czylio podstawach etycznych w biomedycynie, [w:] Bioetyka personalistyczna wobec wyzwań biomedycyny [,,Scripta Theologica Thoruniensia” (2011) nr 18], Z. Wanat (red.), Toruń 2011 s. 21-23.

„Zważywszy, że uznanie przyrodzonej godności oraz równych i niezbywalnych praw wszystkich członków wspólnoty ludzkiej jest podstawą wolności, sprawiedliwości i pokoju świata”. Art. 1: „Wszyscy ludzie rodzą się wolni i równi pod względem swej godności i swych praw. Są oni obdarzeni rozumem i sumieniem i powinni postępować wobec innych w duchu braterstwa" (cyt. za Polska Akademia Nauk. Instytut Państwa i Prawa. Centrum Dokumentacji i Informacji Naukowej o Prawach Człowieka, Prawa człowieka. Dokumenty, t. 1: Dokumenty międzynarodowe. Bibliografia polska, Wrocław 1989 s. 24-25). 
2) Godność człowieka domaga się uznania i poszanowania jego podmiotowości. Nikt więc nie może arbitralnie dysponować drugim człowiekiem, uznać go za swoją ,własność” i czynić z nim, co chce.

3) Godność człowieka domaga się traktowania go jako celu samego w sobie, a nie jako środka do celu stojącego poza nim. Innymi słowy, przedmiotem praktyki biomedycznej musi być dobro tego tu oto człowieka. Tenże człowiek nie może być arbitralnie wykorzystany dla dobra innego człowieka (co ma miejsce, na przykład, w rodzeniu czy tworzeniu „dziecka-lekarstwa”, czy też zaspokojeniu sztuczną metodą pragnienia posiadania dziecka przez bezpłodnych rodziców).

4) W godności człowieka uczestniczy cała jego struktura duchowo-cielesna, a w kategoriach biomedycznych - psychosomatyczna. W praktyce oznacza to, że w godności człowieka uczestniczy w jednakowej mierze jego sfera duchowo-wolitywna, jak i cielesna, czyli jego biologia i fizjologia, w całej gamie ich przejawów i pełnionych przez nie funkcji. W dalszej perspektywie oznacza to również, że przedmiotem ingerencji biomedycznej nie jest wyłącznie określona tkanka czy organ, ale zawsze cała osoba jako taka ${ }^{28}$.

Stosowanie do powyższych przesłanek, praktyka biomedyczna musi mieć na uwadze dobro integralne człowieka, czyli zdolność realizowania siebie w wymiarach cielesnym i duchowo-moralnym, naturalnym i nadprzyrodzonym, indywidualnym i społecznym. To zaś konsekwentnie oznacza, że negatywnie muszą być ocenione, nie tylko te ingerencje, które w sposób zamierzony zadają śmierć człowiekowi, niszczą jego zdrowie, naruszają jego integralność. Analogicznie muszą być ocenione także takie praktyki, które nie są konieczne dla ratowania życia fizycznego, a wyrządzają poważną szkodę duchowi-psychice (np. w przeszłości lobotomia, niektóre typy chirurgii plastycznej, niektóre specyfiki lekarskie, niektóre środki antykoncepcyjne). Z drugiej strony taką samą kwalifikację moralną mają takie praktyki, które nie są

28 „Osoba ludzka może urzeczywistniać się jako «zjednoczona całość»; natura ta jest równocześnie cielesna i duchowa. Na mocy zjednoczenia substancjalnego z duszą rozumną, ciało ludzkie nie może być uważane tylko za zespół tkanek, narządów i funkcji; nie może być oceniane na równi z ciałem zwierząt, jest bowiem istotną częścią osoby, która przez to ciało objawia się i wyraża. [...] Interwencja dokonywana na ciele ludzkim nie dotyczy tylko tkanek, narządów i ich funkcji, lecz angażuje również na różnych poziomach samą osobę; pociąga więc za sobą znaczenie i odpowiedzialność moralną, nawet jeśli w sposób domyślny, to rzeczywisty" (Kongregacja Nauki Wiary, Instrukcja o szacunku dla rodzacego się życia ludzkiego $i$ o godności jego przekazywania. Odpowiedzi na niektóre aktualne zagadnienia „Donum vitae”, Rzym 1987, Wstęp, 3). 
konieczne dla ratowania życia, jednak oddziaływując na sferę psychiczną, radykalnie pogarszają kondycję fizyczną człowieka, czy to doraźnie, czy też w przyszłości (np. stosowanie środków przeciwbólowych w sportach ekstremalnych lub siłowych, stosowanie niektórych afrodyzjaków, stosowanie narkotyków czy też tak zwanych „,dopalaczy”) ${ }^{29}$.

\subsection{Między wiarą i bioetyką chrześcijańską}

Zwracając uwagę na troskę o integralne dobro człowieka w ingerencjach biomedycznych, wskazano jednocześnie na obowiązek poszanowania tegoż wymiaru egzystencji człowieka, który pozostaje w bezpośrednim związku z jego życiem duchowym, moralnym i nadprzyrodzonym. To jedno z wyzwań stojących przed biomedycyną, którego można się dopatrywać w Kodeksie Etyki Lekarskiej, kiedy podkreśla się, że „lekarz powinien zawsze wypełniać swoje obowiązki z poszanowaniem człowieka bez względu na wiek, płeć, rasę, wyposażenie genetyczne, narodowość, w y z n a n i e, przynależność społeczną, sytuację materialną, poglądy polityczne lub in ne uw a r unkowania" (Art. 3).

$\mathrm{Na}$ ten wymiar ingerencji biomedycznych wyraźnie zwraca uwagę Kościół katolicki. W wymiarach generalnych formułuje on zasadę opartą na ontologicznej jedności osoby ludzkiej i na transcendentnym charakterze jej natury: „Każda interwencja na ciele ludzkim nie dotyka tylko tkanek, narządów i ich funkcji, lecz angażuje na różnych poziomach samą osobę. Działalność sanitarna nie może nigdy zapominać o głębokiej jedności istoty ludzkiej, w oczywistej współzależności jej funkcji cielesnych, ale także w jedności jej wymiarów: cielesnego, uczuciowego, intelektualnego i duchowego. Nie można wyizolować problemu technicznego postawionego przez traktowanie określonej choroby od uwagi, jaka powinna być okazana osobie chorego we wszystkich jej wymiarach" ${ }^{30}$. Konsekwentnie przedmiotem troski muszą być nie tylko skutki w zakresie życia fizycznego, ale także mające wpływ na jakość życia duchowego i moralnego pacjenta.

Praktycznym wyrazem tego stanowiska jest, na przykład, stosunek Kościoła do chirurgii plastycznej czy też do stosowania środków znieczulających. W odniesieniu do pierwszego typu działań już papież Pius XII oceniał pozytywnie działania naprawcze i większość ulepszeń

$29 \quad$ Por. J. Wróbel, Antropologia we wspótczesnej refleksji..., dz. cyt., s. 26-27.

30 Por. także Papieska Rada ds. Duszpasterstwa Służy Zdrowia, Karta Pracowników Stużby Zdrowia, Watykan 1995, 40; por. także: Jan Paweł II, Podstawy deontologii lekarskiej. Przemówienie do uczestników zjazdu Światowego Towarzystwa Lekarskiego (29.10.1983), L'OR 4(1983) nr 10, s. 22. 
o charakterze estetycznym. Jednocześnie jednak podkreślał, że ingerencje plastyczne są niedozwolone, kiedy są ,podjęte z intencją wzmożenia zdolności uwodzicielskiej i łatwiejszego zachęcenia innych do grzechu; lub też wyłącznie po to, aby przestępca mógł uniknąć sprawiedliwości"31.

W odniesieniu do drugiego typu działań z jednej strony Kościół uznaje ich dobroczynny charakter, nawet jeżeli w niektórych przypadkach pośrednio mogą przyspieszyć zgon. Jednocześnie podkreśla, że „bez poważnej przyczyny nie godzi się pozbawiać umierającego świadomości. (...) Podanie środków narkotycznych tylko w celu pozbawienia umierającego świadomego końca jest praktyką rzeczywiście naganną. Inna sytuacja zachodzi w przypadku poważnego wskazania klinicznego (...), [to znaczy] ze względu na gwałtowne i nieznośne bóle. Anestezja może być uznana za dozwoloną, ale przy zaistnieniu warunków uprzednich, to znaczy, jeśli umierający zadośćuczynił lub będzie jeszcze mógł zadośćuczynić swoim obowiązkom moralnym, rodzinnym i religijnym" 32 .

Nie są to jedyne wątki związane z pytaniem o wkład wiary w spojrzenie na działania biomedyczne, a tym samym na refleksję bioetyczną. Bardziej ogólną odpowiedź sugerują poczynione już wcześniej refleksje na temat relacji między filozofią i filozofią chrześcijańską. Tak, jak płynące $z$ wiary przesłanki ubogacają odpowiedź na egzystencjalne pytania człowieka, tak również tego typu przesłanki dostarczają jakościowo nowych racji dla zrozumienia dobra w praktyce biomedycznej. Mając na uwadze ramy niniejszego opracowania, można je ująć w kilka przykładowych propozycji:

1) Grecko-semicko-łacińska kultura, inspirowana przez wiarę w Boga Stwórcę i Odkupiciela ukształtowała głęboko humanistyczną duchowość cywilizacji europejskiej, w tym praktyki biomedycznej. Historia tejże cywilizacji pokazuje jednocześnie, że czym bardziej człowiek zatraca ducha wiary i zapomina o swoich kulturowych korzeniach, tym bardziej jest on obdzierany z ludzkiej godności i pozbawiany niezbywalnych praw. Jan Paweł II napisze: „Tracąc wrażliwość na Boga, traci się także wrażliwość na człowieka, jego godność i życie"33.

$31 \quad$ Discours aux membres du $X^{e}$ Congrès national de chirurgie plastique. Przemówienie do uczestników X kongresu chirurgii plastycznej (04.10.1958), [w:] Documents Pontificaux de Sa Sainteté Pie XII, 1939-1958, t. 18, opr. S. Delacroix, Saint-Maurice - Paris - Louvain 1959, s. 572.

Papieska Rada ds. Duszpasterstwa Służy Zdrowia, Karta Pracowników..., dz. cyt., nr 124. 
2) Wiara wskazuje na znaczenie Dekalogu w życiu moralnym człowieka, a konsekwentnie również na doniosłość piątego przykazania - „Nie będziesz zabijał” (Wj 20,13). Jakkolwiek w sensie ścisłym przykazanie to zakazuje niszczenia niewinnego życia ludzkiego (por. Wj 23,7), to jednak cała chrześcijańska tradycja dostrzega w nim także zakaz naruszania cielesnej integralności człowieka oraz nakaz troski o jego zdrowie i życie. W taki sposób przykazanie to przedstawia również Katechizm Kościoła Katolickiego. Kwestie dotyczące poszanowania życia ludzkiego i troski o zdrowie zostają omówione $\mathrm{w}$ ramach piątego przykazania Bożego ${ }^{34}$.

3) Wiara pozwala odczytać postawę Boga wobec życia i zdrowia człowieka. On objawia siebie jako „obdarowującego życiem” (por. Rdz 1, 1-2, 23) oraz jako „Miłośnika życia” (por. Mdr 11, 26). $\mathrm{Z}$ punktu widzenia przesłania biblijnego choroba i cierpienie są złem, którego On nie chce. One zafałszowują Jego ojcowski zamiar i niszczą piękno stworzenia. Konsekwentnie Pismo Święte eksponuje też odpowiedź Boga na to zło. Bóg objawia siebie jako Lekarza, sam cudownie interweniuje, przywracając zdrowie choremu człowiekowi (por. np. Lb 21, 4-9; $2 \mathrm{Krl} \mathrm{5,} \mathrm{1-14;} \mathrm{Mdr} \mathrm{16,}$ 10-12). W innych przypadkach działa On przez ludzi, obdarowując odpowiednimi umiejętnościami lekarza oraz udzielając mocy uzdrawiającej naturalnym środkom leczniczym (,Nie zioła ich uzdrowiły ani nie okłady, lecz słowo Twe, Panie, co wszystko uzdrawia" - Mdr 16, 23). Wiara w taką postawę Boga wobec choroby i cierpienia inspiruje również człowieka do pełnej ufności modlitwy oraz prośby o dar uzdrowienia, a z drugiej strony do wdzięczności za przywrócone zdrowie (np. Ps 6,$3 ; 16,19 ; 30,3$; 32, 3 nn.; 38; 41, 5; 51, 9 nn.; 107, 17 nn.) ${ }^{35}$.

4) Wiara otwiera człowieka na przyjęcie Dobrej Nowiny Jezusa Chrystusa, który proklamuje jako pierwsze i najważniejsze ,przykazanie miłości Boga i bliźniego" (Mt 22, 36-39). Tą miłością jest otaczany cały człowiek. Stąd też miłosierdzie okazane przez Pana Jezusa chorym i cierpiącym w postaci cudownych uzdrowień (por. np. Mt 10, 8; Mk 6, 13.18; Łk 9, 2.6); stąd uczynki miłosierdzia nie tylko wobec ducha, ale również wobec ciała: „Pójdźcie, błogosławieni Ojca mojego, weźcie w posiadanie królestwo, przygotowane

Katechizm Kościoła Katolickiego, Poznań 2002, 2258-2297.

Por. J. Wróbel, Eklezjalny wymiar troski o zdrowie człowieka, [w:] Scio cui credidi. Księga pamiątkowa ku czci Księdza Profesora Mariana Ruseckiego w 65. rocznicę urodzin, I. S. Ledwoń (red.), Lublin 2007, s. 1047-1049. 
wam od założenia świata! Bo byłem [...] byłem chory, a odwiedziliście Mnie" (Mt 25, 34-36). Wiara oparta na Objawieniu pozwala także głębiej poznać tajemnicę Chrystusowego krzyża i w nim odczytać sens ludzkiego cierpienia. Wiara pozwala również dojrzeć w Jezusie Chrystusie Zmartwychwstałym Źródło życia i Światło oświetlające dramat ludzkiego umierania i śmierci ${ }^{36}$.

5) W powyższej perspektywie wiara dostarcza ostatecznych racji uzasadniających godność człowieka i wynikające z niej niezbywalne prawa, ze szczególnym wskazaniem na te przypadki, kiedy wyraziste rysy jego człowieczeństwa pozostają jeszcze w ukryciu, bo na poziomie embrionu lub zostają zniekształcone przez kalectwo.

6) Wiara dostrzegająca w człowieku wymiar duchowo-moralny, chroni go przed czysto biologistycznym ujmowaniem, zredukowaniem go do poziomu zwykłej agregacji komórek, tkanek i organów. Jednocześnie wskazuje na duchowe i moralne potrzeby człowieka przekraczające ramy jego biologii i fizjologii.

7) Wiara nadaje w pełni ludzki kształt inicjatywom i działaniom człowieka, broniąc go przed duchowo-moralnym skarłowaceniem oraz utylitarystyczno-kwantytatywną oceną wartości jego życia.

8) Głęboko przeżywana wiara uwrażliwia człowieka na dobro i rodzi wezwanie do bycia świadkami „Ewangelii życia” i „cywilizacji miłości”37.

Konkludując należy stwierdzić, że wiara, czy to jako osobiste doświadczenie Boga, czy też jako credo wypełnione teologiczną refleksją, może służyć cenną pomocą, a niekiedy dostarczyć ostatecznych racji bioetyce. Innymi słowy, bioetyka zdolna w całej pełni uczynić zadość oczekiwaniom ludzkiego sumienia, potrzebuje nadprzyrodzonego spojrzenia i przesłanek przekraczających naturalne zdolności poznawcze człowieka.

\section{Czy wiara potrzebuje bioetyki?}

Rodzi się jeszcze pytanie, czy równie cenną rolę może spełnić bioetyka wobec wiary? W szerokim rozumieniu taką rolę pełni ona już w kręgu

$36 \quad$ Por. Jan Paweł II, List apostolski o chrześcijańskim sensie ludzkiego cierpienia Salvifici doloris, Rzym 1984; por. także J. Wróbel, Eklezjalny wymiar troski..., dz. cyt., s. 1049-1052.

37 Por. EV, 29-51, 78-101. Por. także I. Mroczkowski, Chrześcijańskie zasady nowej kultury życia. O odwagę nowego stylu życia, [w:] Jan Paweł II, Evangelium vitae. Tekst $i$ komentarz, Lublin 1997, s. 223-236; A. Derdziuk, Modlitwa jako postawa stu̇̇enia Ewangelii życia, [w:] Jan Paweł II, Evangelium vitae. Tekstikomentarz, s. 401-415. 
spotkania bioetyki (zwłaszcza inspirowanej wiarą) z biomedycyną. Człowiek z wrażliwością metafizyczną, próbujący zrozumieć prawdę ukrytą w każdym napotkanym misterium otaczającego go świata, z reguły doświadcza wielkiej fascynacji, kiedy staje wobec tajemnicy człowieka wpisanej w jego biologię, fizjologię, procesy umysłowe i bogactwo duchowe. Człowiek w swojej strukturze bytowej jawi mu się jako wspaniałe odbicie Bożej Mądrości i stwórczego działania, tu i teraz.

Próba ścisłej odpowiedzi na postawione pytanie odsyła do podstawowego dogmatu nauk zajmujących się fenomenem religii. Stwierdzają one, iż możliwa jest moralność bez religii, ale religia nigdy nie funkcjonuje bez zasad moralnych, bez określonego systemu etycznego czy też teologicznomoralnego. Każda religia posiada bowiem swój obraz Boga i konkretne wyrazy odniesienia do Niego w formie aktów kultu oraz zasad moralnego postępowania. Istotnym wyrazem tej relacji są konsekwentnie określone postawy moralne. Tak już w Starym Testamencie relację Narodu Wybranego z Bogiem Jahwe określa Przymierze z właściwymi mu zobowiązaniami ujętymi w Prawie, a nade wszystko w Dekalogu nakazującym w piątym przykazaniu szanować ludzkie życie i zdrowie. Niezbywalność tej relacji podkreśla św. Jakub Apostoł, kiedy pisze: „Jaki z tego pożytek, bracia moi, skoro ktoś będzie utrzymywał, że wierzy, a nie będzie spełniał uczynków? Czy sama wiara zdoła go zbawić? (...) Tak też i wiara, jeśli nie byłaby połączona z uczynkami, martwa jest sama w sobie. Ale może ktoś powiedzieć: Ty masz wiarę, a ja spełniam uczynki. Pokaż mi wiarę swoją bez uczynków, to ja ci pokażę wiarę na podstawie moich uczynków” (Jk 2, 14-18).

Powyższa zależność wynika z samej natury wiary. Zgodnie z określeniem Katechizmu Kościoła Katolickiego, „wiara «jest najpierw osobowym przylgnięciem człowieka do Boga; równocześnie i w sposób nierozdzielny jest ona dobrowolnym uznaniem całej prawdy, którą

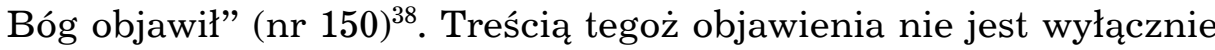
immanentna tajemnica Boga Trójjedynego, ale równie bardzo prawda o człowieku i zasadach jego wierności Bogu. Papieska Komisja Biblijna w dokumencie Biblia a moralność. Biblijne korzenie postępowania chrześcijańskiego napisała na ten temat: „Kompleks normatywny jest konsekwencją wskazania człowiekowi, jaki jest właściwy sposób przyjęcia daru Bożego i życia nim"39.

Zgodnie z uczynionymi nieco wyżej uwagami, już w Starym Testamencie podstawę Przymierza z Bogiem stanowi Dekalog. W rzeczywistości

$38 \quad$ Por. także Kongregacja Nauki Wiary, Nota zawierająca wskazania duszpasterskie na Rok Wiary, Rzym 07.01.2012, Wprowadzenie. 
Nowego Testamentu zachowuje on niezmiennie swoją aktualność (por. Mt 5, 17-48; 19, 16-19), mimo iż Pan Jezus proklamuje „nowe przykazanie” (J 13, 34-35), „największe i pierwsze przykazanie miłości Boga i bliźniego" (Mt 22, 36-40). Jednocześnie Pan Jezus wskazuje na wzajemną korelację zachodzącą między Dekalogiem i „nowym przykazaniem". Dekalog stanowi wewnętrzną treść przykazania miłości, a ono z kolei stanowi „duszę” Dziesięciu Przykazań (por. Mt 22, 40). Stąd troska o życie i zdrowie bliźniego stanowi praktyczny, „największy i pierwszy" wyraz miłości bliźniego.

W kontekście prowadzonych analiz życie jawi się jako największy dar udzielony człowiekowi w porządku naturalnym - podstawa wszystkich innych darów. Przez to, że jest darem Bożym i swoją pełnię osiąga w zjednoczeniu z Nim, jest ono wprost darem świętym i jako takie jest ono wyłączną ,własnością” Boga. Stąd Jan Paweł II podkreśla, iż „życie, zwłaszcza ludzkie, należy wyłącznie do Boga: kto podnosi rękę na życie człowieka, podnosi niejako rękę na samego Boga"40. Przed takim występkiem ma chronić człowieka piąte przykazanie Dekalogu - „Nie zabijaj”.

Mając na uwadze płynące $\mathrm{z}$ wiary przesłanie na temat ludzkiego życia, bioetyka pełni wobec niej niebagatelną rolę. Pozwala ona rozpoznać powinność moralną w kręgu zawiłych dylematów praktyki biomedycznej, a w dalszej perspektywie postępować zgodnie z wymogami wiary i moralnego dobra. $Z$ drugiej strony bioetyka chroni człowieka przed zatraceniem duchowo-moralnej wrażliwości, co łatwo owocuje negacją moralnego dobra jako prawdziwą powinnością oraz ludzkim życiem jako pierwszym darem udzielonym człowiekowi przez Stwórcę i znajdującym się pod Jego ojcowską pieczą. Jan Paweł II przestrzega przed takim procesem zaznaczając, że ,systematyczne łamanie prawa moralnego, zwłaszcza w poważnej materii poszanowania życia ludzkiego i jego godności, prowadzi stopniowo do swoistego osłabienia zdolności odczuwania ożywczej i zbawczej obecności Boga" ${ }^{41}$. W wymiarze pozytywnym bioetyka, jako podstawa moralnego postępowania, przyczynia się jednocześnie do duchowego wzrostu człowieka. Dzięki niej człowiek rozpoznaje piękno udzielonego mu przez Stwórcę daru i bezkres życiowej szansy.

Słowa kluczowe: bioetyka, wiara, etyka chrześcijańska, bioetyka naturalna, bioetyka chrześcijańska, biomedycyna, norma personalistyczna

$\begin{array}{ll}40 & \mathrm{EV}, 9 . \\ 41 & \mathrm{EV}, 21\end{array}$

